\title{
Missionárias norte-americanas na educação brasileira: vestígios de sua passagem nas escolas de São Paulo no século XIX*
}

\author{
Jane Soares de Almeida \\ Universidade Metodista de São Paulo, Programa de Pós-Graduação em Educação
}

\section{Introdução}

Ao expandir-se e assumir uma política externa mais agressiva no século XIX, o sistema capitalista dos Estados Unidos utilizou como suporte os ideais liberais, divulgando não só o pensamento, mas o estilo de vida, a crença religiosa, a visão de mundo, a postura ética e os hábitos de trabalho e de poupança da sociedade norte-americana, o que seria popularizado nos países campo de missão principalmente pelas igrejas e instituições escolares. Essa influência transpareceria na ideologia de caráter liberal que se implantou no Brasil no século XIX, ainda mais fortemente após a República. O contexto histórico e político-econômico que o Brasil atravessava propiciou a entrada e veiculação do protestantismo, o que contribuiu para uma renovação

* Pesquisa apoiada pelo Conselho Nacional de Desenvolvimento Científico e Tecnológico (CNPq) na modalidade bolsa de produtividade em pesquisa. Também contou com financiamento da Fundação de Amparo à Pesquisa do Estado de São Paulo (FAPESP) com bolsa de pós-doutorado no exterior. ideológica após quase quatrocentos anos de predomínio absoluto do catolicismo.

Embora estruturado como um catolicismo de aparências desde a Colônia, em que os comportamentos políticos e morais (não necessariamente de acordo com os princípios religiosos cristãos) se sucediam sob os olhos complacentes do clero e devidamente acobertados pelos rituais da absolvição, a presença do catolicismo na vida social e política do país sempre foi referencial. Sob as vistas da Igreja católica impuseram-se reformas e ditaram-se regras educacionais, num embate de caráter ideológico no qual o clero aspirava manter indefinidamente a hegemonia religiosa.

Os protestantes que aportaram no Brasil em meados do século XIX para divulgar sua crença religiosa encontraram um país com uma cultura que apresentava elementos favoráveis à sua implantação, mesmo considerando-se a inevitável oposição que viria do clero católico, perpetuando o antagonismo iniciado na Reforma. Os diversos grupos missionários foram precedidos por outros grupos protestantes pertencentes às sociedades bíblicas norte-americanas e britânicas, que 
abriram espaço para os demais, como os metodistas, os presbiterianos, os congregacionais, os batistas e os episcopais, que consideravam a religião evangélica uma alternativa à religião oficial adotada. As colônias estabeleceram-se em São Paulo, Rio de Janeiro, Espírito Santo, Pará, Bahia, Rio Grande do Sul, Paraná, entre outros locais. ${ }^{1}$ Em São Paulo, os missionários fixaramse no litoral ou embrenharam-se pelo interior da província, apresentando o Novo Testamento e conquistando adeptos para a nova religião pela divulgação do hinário religioso e alfabetizando a população para que esta pudesse ler a Bíblia. Nesse período, principalmente nos povoamentos interioranos, a educação era algo difícil e de remota aquisição, o que resultava numa grande parcela de analfabetos. Os primeiros missionários protestantes, nas suas andanças pelo sertão pregando o evangelho, também ensinavam os hinos que eram cantados em reuniões familiares, faziam amigos entre os moradores da província e preparavam o terreno para a nova religião e para um novo ideal de vida. Nos relatórios à Board of Foreign Mission, em Nova York, veiculavam a imagem de um território "vasto, pitoresco, amável, acessível aos protestantes, e de futuro; mas, principalmente, como país de missão, ao qual as igrejas protestantes deviam enviar missionários" (Ribeiro, 1981, p. 14).

Em maio de 1859, a Assembléia Geral da Igreja Presbiteriana ${ }^{2}$ nos Estados Unidos aprovou o relató-

1 “[...] difícil dizer se a 'Guerra Civil' e a 'reconstrução' foram as causas principais dessas imigrações. Pode-se, porém, afirmar que, segundo certa estimativa, dos 10.000 sulistas, aproximadamente, que deixaram os Estados Unidos depois da Guerra de Secessão, cerca de 2.000 sulistas em sua maioria radicaram-se no Brasil. Haviam perdido seus escravos, ou melhor, o estilo de vida que a escravidão lhes proporcionava. Visavam, por conseguinte, fixar-se num país onde ainda vigorava o regime econômico de sua preferência, embora alguns dos que os chefiavam já tivessem previsto que também no Brasil a escravidão estava prestes a extinguir-se" (Goldman, 1972, p. 10).

${ }^{2}$ Escolhi para ilustrar este trabalho o ramo do protestantismo presbiteriano por este ter tido uma maior representatividade rio encaminhado pela Junta das Missões Estrangeiras de Nova York, no qual constavam as informações dos primeiros missionários que descreviam o Brasil como terreno fértil para a implantação do protestantismo. O território vasto, a população relativamente pequena, o clima saudável e os recursos inexplorados, além de um governo liberal, de acordo com os missionários, faziam da nação brasileira local de grande potencial para um dia ser uma das mais importantes economias do mundo. Portanto, era conveniente envidar esforços para introduzir no país princípios religiosos corretos, uma vez que consideravam o clero católico omisso, seus representantes não primando pela moralidade e dando péssimos exemplos ao povo (idem). A aprovação do relatório fez com que a Junta das Missões Estrangeiras nomeasse o reverendo Ashel Green Simonton para fundar igrejas e pregar o evangelho, alicerçando o futuro do protestantismo no país pelo ramo presbiteriano. ${ }^{3}$

Simonton desembarcou no Rio de Janeiro em 1859 , onde criou a Igreja presbiteriana, e no ano seguinte viajou para São Paulo e pelo interior da província, onde sempre era bem recebido pelos brasileiros, conforme atestam suas cartas e relatórios à junta. Em suas viagens pelo interior, constatou o abandono cristão e educacional da população em geral, e em especial dos protestantes imigrados, que não podiam casar-se, batizar seus filhos e enterrar seus mortos nos cemitérios, dado que o que vigorava eram os preceitos católicos. Durante sua passagem pelo interior, Simonton verificou que nas diversas vilas havia protestantes que necessitavam de um pastor, e a junta, a

em São Paulo e nas vilas do interior, embora os demais ramos também tenham fundado suas igrejas e suas escolas.

3 "Verifica-se nesse período, já que as circunstâncias globais se apresentavam favoráveis, a chegada de grande número de missões norte-americanas: Missão Metodista Episcopal (1870), Missão Presbiteriana do Sul dos Estados Unidos (1869), Missão Batista (1881), Missão Episcopal (1890), que vieram juntar-se aos Congregacionais (1855) e aos Presbiterianos do Norte (1859), e ainda aos Luteranos (1823)" (Ramalho, 1976, p. 57). 
seu pedido, contratou o reverendo Christopher Schneider, alemão naturalizado norte-americano, que chegou a São Paulo em 1861. Daí deslocou-se para Campinas e Limeira, indo depois se fixar em São João do Rio Claro, que na época contava com aproximadamente 2.500 habitantes. Entre estes, havia imigrantes suíços e alemães que também se concentraram em Limeira e Piracicaba desde o século anterior, tendo vindo trabalhar nas lavouras das grandes fazendas, substituindo a mão-de-obra escrava. Rio Claro transformou-se num local por excelência da propagação das idéias protestantes no interior paulista, e a vila tornou-se um centro de afluência dos demais missionários. Esses homens veicularam entre a população local valores morais e éticos, além de introduzirem os princípios dos ideais democráticos e liberais que abraçavam em seu país de origem. Muitas vezes conseguiam até mudar comportamentos sociais e políticos de exploração de raça e classe, próprios da elite detentora do poder local, possuidora de uma mentalidade escravista e dominadora. ${ }^{4}$

A partir de 1870, incentivados por um sistema político que, pelo menos teoricamente, oferecia liberdade de crença, os missionários sentiram-se ainda mais confiantes em vir para o Brasil. Estavam imbuídos da idéia de aqui alicerçarem sua igreja e divulgarem sua crença e sua ideologia. Essa atitude tinha paralelos com aquilo que acontecia nas missões na Índia, na China e nos demais países da América Latina. Era o imperialismo em sua forma cultural que lançava seus tentáculos pelo mundo civilizado, e plantava, pela via religiosa, as raízes de uma civilização que se considerava o exemplo de um sistema político democrático e que queria expandir-se como nação e, por meio dessa expansão, divulgar e implantar seu modo de vida.

\section{A obra educativa missionária}

Na obra missionária, a educação era um dos principais pontos a serem explorados, e a questão educa-

${ }^{4}$ Essas informações constam do Diário de Simonton (1982), escrito no período de 1852 a 1857. tiva era totalizante. Os norte-americanos não consideravam que sua missão fosse apenas evangelizar; sua ação centrava-se no objetivo de educar indivíduos imbuídos do sentido de coletividade e da aspiração de dar os primeiros passos nos rumos da ascensão social. Isso significava uma concepção de vida que deveria também ser divulgada junto aos nativos, e que se traduzia por uma fé inquebrantável na educação como articuladora de valores sociais tais como liberdade, democracia, solidariedade e responsabilidade individual. Na ação missionária e educativa havia um pretenso sentido de superioridade étnica dos norteamericanos em relação a um povo atrasado e ainda imbuído do ranço clerical. Além disso, boa parte da população opunha certa resistência em aceitar a ideologia protestante, que pregava valores diferenciados, originados de um sistema capitalista que já havia avançado, e que em alguns momentos confrontava com o modo de ser dos da terra. Mesmo assim, não foram poucas as conversões dos brasileiros de todas as classes sociais à nova religião, havendo, inclusive, uma crescente nacionalização do clero protestante (Ramalho, 1976, p. 58).

No final do século XIX, os missionários norteamericanos passaram a vir para o Brasil cada vez em maior número, trazendo esposas e filhas que viriam a incumbir-se do ensino nas escolas, enquanto os maridos divulgavam a doutrina aos nativos da terra e davam a necessária assistência espiritual aos que já professavam ou viessem a adotar a fé protestante. Possuíam esses missionários a crença inabalável dos que se sentem iluminados por Deus para espalhar sua palavra a todos que dela necessitavam, e nisso encontravam forças para enfrentar todos os obstáculos. Era a ideologia do destino manifesto que transparecia nessa postura e que os fazia acreditar serem o povo escolhido para divulgar a verdadeira fé:

A conjunção dessas crenças formou um complexo mitológico sobre o passado, presente e futuro dos Estados Unidos, alimentando a luta expansionista dos americanos que atingiu o ápice na metade do século XIX, quando se constatou um aumento territorial de 1.788 .000 milhas em 
1845, para 2.992.000 milhas em 1849. Foi então que se concretizou definitivamente a idéia do "Destino Manifesto", com o argumento generalizador da liberdade e da democracia para os demais territórios. (Oliveira, 1995, p. 53)

A expansão do território e a intensificação do comércio justificavam a ação missionária, que se processava a mando do imperialismo com o argumento da missão divina, e possibilitava a conseqüente expansão capitalista, o que vinha ao encontro dos interesses econômicos e políticos dos Estados Unidos. Aliava-se a isso a intencionalidade de contar com uma alternativa para a transferência da população negra, que se multiplicava pelos estados após a Guerra de Secessão, e evitar a miscigenação racial no próprio país:

Numa época de intenso debate e preocupação dos estados sulistas em manter sua tradicional instituição escravista, cada vez mais criticada pelos nortistas industriais e comerciantes, o interesse direcionava-se no sentido de encontrar uma base territorial mais sólida para a expansão do sistema escravocrata. Ao mesmo tempo, visualizavase a potencialidade de tais regiões como receptáculos de negros libertos, para evitar a miscigenação que deterioraria a "pureza da raça branca", como sugeriam teorias racistas em voga na Europa. (idem, p. 55)

Apesar do repúdio da Igreja católica ao protestantismo, ocasionalmente houve episódios como o do padre católico que ficou famoso por aliar-se aos missionários. Chamado José Manuel da Conceição, alcunhado de "o padre louco" ou "o padre protestante", cujo nome era constantemente citado nos relatórios à Junta de Nova Iorque, realizaria importante trabalho de evangelização em Rio Claro e Brotas, tendo sido depois excomungado por sua conversão à fé protestante:

[...] ensinava que a Bíblia era a Palavra de Deus e não uma heresia, que as imagens de santos não possuíam nenhuma santidade e que podiam ser atiradas fora como qualquer outro objeto, que não havia obrigação de confissão de pecados ao padre, mas que isso podia ser feito a Deus por intermédio de Cristo.
[...] Homem inconformado e inquieto, quando se encontrou com os missionários presbiterianos, em 1863, iniciou uma jornada que iria ser um dos grandes triunfos do protestantismo no Brasil. (Mendonça, 1984, p. 82)

Nos relatórios à Junta nos Estados Unidos, os missionários referiam-se ao modo afável dos brasileiros, principalmente paulistas e cariocas, seus hábitos livres, as uniões não-legalizadas, a tolerância e o respeito pela religião alheia. A esse respeito escreveu Simonton em 1864:

A Constituição Brasileira garante a liberdade de culto; tanto o Governo como o povo se gabam de serem tão liberais e tolerantes como qualquer nação, seus atos têm comprovado extraordinariamente essa pretensão, tanto aqui [no Rio], como na Bahia. Portanto, impunha-se educar essa população inculta e seus hábitos licenciosos tão em desacordo com a ética protestante. Para isso, a criação de escolas se configuraria como uma das mais significativas obras dos missionários. (Ribeiro, 1981, p. 119)

$\mathrm{O}$ analfabetismo reinante entre homens, mulheres e crianças era um obstáculo à conversão baseada na leitura da Bíblia, dificultando o progresso e a ascensão social, idéia firmemente plantada pela corrente liberal capitalista. Imbuídos dessa crença, os missionários envidariam esforços para a criação de colégios onde pudessem encarregar-se da educação dos brasileiros e convertê-los:

Quase não se tem notícia, nesse período, de iniciativas educativas não-religiosas que por parte das igrejas e missões protestantes não tivessem como objetivo a instituição de uma escola. Embora fosse difícil para um grupo minoritário, liderado por estrangeiros, patrocinar movimentos educativos não-formais, no entanto, o estabelecimento de instituições de ensino eficientes, bem organizadas, com modernas instalações, e que fossem altamente consideradas pelas pessoas importantes da comunidade, era do próprio interesse desse mesmo grupo e correspondia de certa forma à concepção que tinha da estruturação da sociedade. (Ramalho, 1976, p. 74) 
A Igreja católica desenvolvia uma pálida campanha catequista entre a população interiorana valendose de um trabalho apologético que também era defensivo, procurando justificar e fortalecer a prática da religião, inculcando no imaginário dos indivíduos o medo da excomunhão e as sanções que penalizariam aqueles que não obedecessem aos seus dogmas. Alguns párocos costumavam insistir junto à população para que dessem condições aos seus filhos de receber instrução e ensinamentos religiosos, porém isso também não parecia resultar em ações concretas. Em contrapartida, o hábito dos missionários de chegarem até as casas, oferecerem bíblias de graça, ensinarem salmos, orações e hinos parece ter resultado mais eficiente do que a insistência dos párocos e a obrigatoriedade do ensino religioso nas escolas. A possibilidade de alfabetizar-se, e dessa maneira poder ler a Bíblia, o que não era possível no catolicismo, deve ter atraído a população provinciana para o protestantismo, embora se possa supor que ela nunca abandonou totalmente as crenças e a imagética católica, na qual se camuflava a religião dos escravos e seus deuses, que costumavam transformar as manifestações religiosas em festa.

Com a estruturação do republicanismo e a veiculação em maior escala das premissas liberais e positivistas, as escolas protestantes passaram a ser aceitas pelas famílias mais importantes em todo o país. Pela educação da elite pretendia-se atingir a população em geral, formando líderes evangélicos que atuassem efetivamente na sociedade: "esses líderes, mesmo que não tenham pessoalmente se convertido ao protestantismo, recebem a influência evangélica nas suas vidas, e mais tarde, quando estiverem ocupando cargos de importância no País, poderão divulgar, compreender e facilitar a expansão do protestantismo e suas idéias" (Ramalho, 1976, p. 78).

Na segunda metade do século XIX chegaram ao Brasil as diversas denominações do protestantismo, como os metodistas, os congregacionais, os batistas e os presbiterianos, consideradas protestantismo de imigração, provenientes das missões norte-americanas. Em 1836, grupos de imigrantes anglo-saxônicos fun- daram uma sociedade metodista, o que pode ser considerado o início do movimento missionário norteamericano. A primeira preocupação dos missionários presbiterianos quando chegaram ao país foi a instalação de escolas que viriam a tornar-se instituições importantes, como o Instituto Gammon de Lavras, fundado em 1869; o Mackenzie College de São Paulo, em 1870; o Ginásio Evangélico Agnes Erskine, em Recife, em 1904; o Instituto Ponte Nova, em Wagner na Bahia, em 1906; o Colégio Quinze de Novembro, em Garanhuns, em 1907; o Instituto Cristão, em Castro, em 1915; o Colégio Evangélico do Alto Jequitibá, em Presidente Soares, em 1923; o Colégio Evangélico de Buriti, em 1924; o Instituto José Manuel da Conceição, em Jandira, em 1928; o Colégio Dois de Julho, em Salvador, em 1928 (idem, p. 81).

No interior paulista, as escolas foram criadas primeiramente em vilas como Botucatu, Rio Claro, Santa Bárbara, Brotas, São Carlos do Pinhal, Piracicaba, Ribeirão Preto, Araraquara, entre outras. Nesta última funcionou, até aproximadamente 1924, um colégio também denominado Mackenzie. Nessas escolas eram educados os filhos dos imigrantes e da população mais pobre, pois no interior o preconceito contra os protestantes colocava algumas dificuldades em atingir as classes mais bem situadas economicamente. Aliás, para os abastados interioranos enriquecidos com o plantio do café explorado pela mão-de-obra imigrante, colocar os filhos na escola pública era uma vergonha à qual não costumavam expor-se; o que não dizer então de colocá-los numa escola não católica?

\section{Para cada igreja, uma escola}

As pequenas escolas, criadas no interior da província de São Paulo nos moldes de para cada igreja, uma escola, não foram determinantes na ação educativa missionária, mas sim os colégios endereçados à elite e a uma classe média que, na capital paulista e no interior, incorporavam cada vez maior poderio econômico e intelectual. Uma educação liberal, de acordo com os ideais norte-americanos, e voltada para os 
interesses do capitalismo, seduziria as classes dominantes e os setores progressistas da sociedade brasileira que seriam atraídos pelos métodos pedagógicos e estilo de vida propagados nesses colégios. A escalada protestante pela província de São Paulo contribuiu para certa expansão do acesso à escolaridade no interior paulista, que, se era precário na capital nesse período, no interior era praticamente inexistente, a população permanecendo quase que inteiramente analfabeta, com o beneplácito do poder público e a omissão da Igreja católica.

Nos anos de 1870 do século XIX, o reverendo João Fernandes Dagama, calvinista exilado da ilha da Madeira, chegou à Vila de Rio Claro, no interior do estado de São Paulo, onde organizou a Igreja presbiteriana e logo depois a Escola Americana. Em seguida foi para Araraquara e erigiu uma igreja, em 1873. Voltando a Rio Claro em 1877, criou um internato e externato para órfãos que funcionou até 1886. A escola notabilizou-se por possuir excelentes mestras e dar um ensino de boa qualidade. Imbuído do mais autêntico fervor religioso, Dagama viajou por diversas cidades interioranas lançando as bases de novas igrejas e, sempre que possível, fundando escolas, pois havia que se alfabetizar a população inculta e dar-lhe condições educativas de ler a Bíblia e dessa forma receber a palavra de Deus. Era essa a principal aspiração dos missionários, e para isso submeteramse ao clima quente, sofreram perseguições, enfrentaram doenças como malária e febres persistentes, tiveram dificuldade de adaptação ao país, não sendo poucos os que não resistiram e voltaram à pátria, ou morreram vitimados por moléstias, bem dentro do espírito de trabalho e pregação - a ética protestante de que nos fala Weber (1981, p. 211):

Isto porque todos, sem exceção, recebem uma vocação da Providência Divina, vocação que deve ser por todos reconhecida e exercida. Essa vocação não é, como no luteranismo, um destino ao qual cada um deva se submeter, mas um mandamento de Deus a todos, para que trabalhem na sua glorificação.
A abertura de escolas em lugares distantes da igreja, em dias de descanso religioso, o sabbath, também foi uma maneira de atingir uma parcela da população que se espalhava em pequenas vilas interioranas de difícil acesso e onde os representantes do clero não costumavam chegar. Para essa população, colocada em orfandade católica, a religião era bem-vinda e possibilitava casamentos e batizados, além da devoção cotidiana. $\mathrm{O}$ que dizer de uma escola que ensinasse as primeiras letras para meninos e meninas com dificuldades de acesso à educação pública ou católica? Portanto, os missionários dedicados à educação constituíam uma missão à parte, conforme pensamento da Junta de Nova York, e em suas mãos repousava o primeiro caminho para levar a palavra do Senhor à população.

O ideário pregado pelos missionários, de uma educação que atingisse a toda a população, e que o ensino de crianças estivesse sob responsabilidade feminina, fez com que as mulheres ocupassem um lugar destacado na obra educativa. A concepção de trabalho como vocação e de glorificação da palavra de Deus, de acordo com a ascese protestante, não poderia alijar da sua realização o sexo feminino, por mais difícil que este se apresentasse. Ao contrário do espírito religioso católico e ainda atrelado ao colonialismo lusitano, que via o trabalho feminino como desairoso, para os protestantes impedir as mulheres de trabalhar seria também impedir a exposição da vontade divina.

\section{Professoras e missionárias: the soldiers of love}

Apesar da orientação norte-americana de, no final do século XIX, atribuir às mulheres a incumbência de educar a infância, muitas vezes os membros da Junta de Nova York manifestaram dúvida e preocupação quanto à possibilidade de as missionárias ensinarem meninas nos lugares ermos do interior, por conta das privações e riscos a que eram submetidos os evangelizadores. Uma preocupação que também se referia ao seu próprio país, com o perigo das grandes extensões territoriais e com a vida em estado quase 
selvagem nas fronteiras mais distantes. Porém, também entendiam a necessidade desse trabalho, já que para a importante tarefa educativa todos os recursos humanos deveriam ser aproveitados, principalmente quando se tratava de um país católico, subjugado por um clero ao qual atribuíam epítetos de "inepto e cheio de vícios", vivendo em desacordo com a moral cristã e sem nenhum código de ética, como o adotado no protestantismo.

Em 1863 chegaram a São Paulo o reverendo Alexander Latimer Blackford ${ }^{5}$ e sua esposa Elizabeth, respectivamente cunhado e irmã de Simonton. Vindos para substituir o reverendo Christopher Schneider haviam desembarcado no Rio de Janeiro em julho de 1860. O casal instalou-se em São Paulo, onde ministrava cultos em inglês nas manhãs de domingo, e às tardes em português, celebrando também batizados e casamentos, além de sessões de estudo da Bíblia. Em pouco tempo, eles estavam enfrentando os sertões interioranos em busca de fiéis. Mesmo otimistas com a missão a eles confiada, preocupavam-se com os clérigos, algumas vezes hostis, assim como com parcelas da população que não viam com bons olhos uma religião diferente. Assustavam-se com a falta de higiene e as múltiplas doenças que grassavam entre o povo, a devassidão de costumes, as mancebias freqüentes, o paganismo das crianças e, pior ainda, não compreendiam a indiferença em relação à vida espiritual que a população expressava, tão em desacordo com seu modo de vida, voltado para o total acatamento dos preceitos religiosos. Também se surpreen-

${ }^{5}$ A correspondência de Blackford com a Junta dos Estados Unidos e com pessoas de seu círculo de relações encontra-se arrolada em uma coleção de microfilmes. As cartas são numerosas e referem-se muitas vezes à criação de escolas erigidas em prédios ao lado das igrejas nas cidades do interior, queixando-se freqüentemente da falta de verbas para mantê-las e da necessidade da população em instruir-se para conhecer o evangelho e a verdadeira religião. A correspondência é em inglês, e manuscrita em ambos os lados do papel, o que dificulta bastante a leitura (BrazilMission, 1833-1911). diam com a ação dos padres católicos, que agiam como mediadores do vínculo entre os homens e Deus, distribuindo absolvições em troca de pequenos favores, diferentemente dos protestantes, que pregavam a relação direta com Deus sem a mediação dos pastores. Para os protestantes, no enfrentamento com o poder divino não deveria haver lugar para deslizes ou negociações perante os pecados cometidos; para os católicos, os pecados poderiam ser negociados em troca de benefícios para a sua igreja. Eis a síntese da diferença entre os dois grupos cristãos.

A criação de escolas ao lado das igrejas, que enfrentavam a proibição de erigir-se em torres para o alto como as católicas, era devida ao fato de o pastor presbiteriano, "desde tempos remotíssimos, receber dos pais o compromisso de ensinar a criança a ler a palavra de Deus" (Ribeiro, 1981, p. 183). A alfabetização era o caminho para levar à leitura da Bíblia, e nisso levavam vantagem sobre o clero católico, que utilizava o latim, inacessível para o povo, além de a sua leitura ser privilégio apenas dos padres, por sua exigüidade e pouca circulação entre os devotos.

$\mathrm{O}$ reverendo Blackford tinha as mesmas preocupações que Simonton em relação à criação de classes para os filhos dos convertidos. Ambos acreditavam que, para o futuro das igrejas evangélicas no Brasil, oferecer escolas para essas crianças era um meio indispensável para conseguir fidelidade religiosa e atrair novos adeptos. Existia implícita a idéia, também centrada na ética protestante, de que "o evangelho dá estímulo a todas as faculdades do homem e o leva a fazer maiores esforços para avantajarse na senda do progresso". ${ }^{6}$ Essa concepção imbricava-se com a postura liberal de colocar no indivíduo a responsabilidade pelo seu sucesso ou fracasso, traços fortemente marcados na ideologia norte-americana, além de conjugar-se aos esforços incipientes do capitalismo em levar os povos latino-americanos à idéia da prosperidade material como agradável aos

${ }^{6}$ Do relatório de Simonton ao Presbitério, em 1867 (apud Ribeiro, 1981, p. 184). 
olhos de Deus, exatamente o contrário da pregação católica.

Enquanto os católicos, apoiados pela Igreja, tinham resistência ao trabalho feminino fora do lar, Blackford considerava as mulheres excelentes mestras de crianças de ambos os sexos. Isso diferia do ideário católico que, quando muito, as tinha talhadas para lecionar apenas para as meninas, repudiando-se inclusive as aulas no sistema misto de ensino por parte de segmentos mais conservadores. Apesar das preocupações com sua segurança e conforto, as missionárias costumavam corresponder às expectativas, e Ella Kuhl, Margareth Scott, Mary Dascomb e Clara Hough, entre outras, foram enviadas ao Brasil pela junta para criar escolas e organizar seu projeto pedagógico de acordo com o método de ensino norte-americano. Muitas foram as dificuldades, principalmente os cortes financeiros que afetavam as escolas, e as professoras missionárias chegavam mesmo a cobrir gastos com seu próprio salário, conforme escreveu Ella Kuhl para Mary Dascomb em janeiro de 1899 . $^{7}$

A junta, em Nova York, costumava acatar os constantes pedidos de ajuda por parte dos missionários. Seus membros também comungavam a mesma idéia acerca do valor da instrução para o êxito da empreitada protestante, e enviavam para o Brasil homens e mulheres com o objetivo de divulgar não só a fé religiosa, como o ensino segundo os preceitos norteamericanos, além de colaborar para o pagamento de salários dos professores brasileiros convertidos. Consideravam o Brasil um importante e promissor campo de missão, chegando mesmo a afirmar que os missionários no estrangeiro sofriam menos privações do que em seu próprio país, referindo-se ao trabalho nas fronteiras do território norte-americano, onde enfrentavam uma terra ampla e ainda selvagem.

Alguns anos depois de Blackford, em 1864 o reverendo George W. Chamberlain chegou a São Paulo, vindo do Rio de Janeiro, onde já havia fundado, juntamente com Simonton e Blackford, a primeira

\footnotetext{
${ }^{7}$ Brazil-Mission (1833-1911, microfilme n. 149).
}

Igreja presbiteriana do Brasil, em 1862. Conforme já foi assinalado, no ano seguinte da sua chegada a São Paulo viajou pelo interior da província, distribuindo bíblias e buscando adeptos para a fé protestante. ${ }^{8}$ Mary Annesley Chamberlain, sua esposa, veio para São Paulo em 1869. Era educadora de sólida experiência, conhecedora dos métodos pedagógicos norte-americanos. Preocupava-se com as crianças crescendo na ignorância pela falta de meios para pagar seus estudos, e com as meninas protestantes vítimas de perseguição religiosa nas escolas. Nisso se incluía a ausência de escolas de qualidade que pudessem educar os filhos e as filhas dos protestantes radicados em São Paulo, assim como as crianças brasileiras vítimas do descaso das autoridades no tocante à educação, além dos filhos dos republicanos e defensores da abolição, dos positivistas e dos liberais, discriminados por católicos e monarquistas.

A missionária começou a lecionar numa classe para meninas que montou na sala de jantar de sua casa e que, pouco tempo depois, não mais comportava a grande afluência de alunos, tornando-se urgente encontrar um espaço maior para receber a todos. Configurava-se no Brasil um momento histórico no qual as idéias que corriam estavam em efervescência e referendavam os debates entre políticos liberais de diferentes tendências religiosas, e até mesmo daqueles que não professavam qualquer fé.

Em 1870, a junta passou a enviar dinheiro para ajudar a manter a escola, que até então funcionava com os proventos do casal, dando autorização para que esta se estabelecesse num local maior. A escola mudou-se para uma casa de cultos, e em 1871 chegaram mais professores para ajudar nas aulas.

8 “Ao final de 1865, o resultado de seus trabalhos frutificaram: duas igrejas nasceram na Província de São Paulo, uma na capital, no dia 5 de maio, e outra em Brotas, no dia 13 de novembro. Nesse mesmo ano, Simonton, Blackford e Schneider constituíram na capital do Império o Presbitério do Rio de Janeiro, subordinado à Assembléia Geral da Igreja Presbiteriana dos Estados Unidos" (Mackenzie, 1997, p. 33). 
Nesse período, a presença das mulheres na educação escolar pública paulista fazia-se cada vez mais freqüente, mas ainda era vista com resistência por parte de segmentos conservadores mais tradicionais; no interior da província, as professoras primárias públicas enfrentavam preconceitos diversos, que se apoiavam na imagética colonial de o trabalho ser nocivo para as mulheres e até mesmo atentar contra a sua formação moral. Isso acontecia a espaços, apesar de o ideário positivista alocar ao sexo feminino a tarefa de educar a infância, o que permaneceria por décadas após a República. Essas mulheres, tanto as norteamericanas como as brasileiras convertidas que abraçaram seus propósitos educacionais, além da educação dos meninos e meninas, empenharam-se na formação de novos quadros profissionais que pudessem dar continuidade ao seu trabalho em esfera local. Para isso investiram na criação de escolas que pudessem não só educar meninos e meninas, como formar professores e professoras para o ensino primário, que em fins do século passava por tentativas de implantação e reforma em São Paulo.

Dentre as missionárias, há que destacar Mary Parker Dascomb, professora nomeada pela Junta de Nova York que esteve lecionando no Rio de Janeiro por volta de 1866. Logo depois viriam Palmyra Rodrigues, Adelaide Molina e miss Harriet Greemann. Em 1885, Horace Manley Lane foi convidado pelo reverendo Chamberlain para dirigir a escola americana que posteriormente, em 1894, chamou-se Mackenzie College, instituição patrocinada pelo filantropo americano John T. Mackenzie. Ao mesmo tempo, foram criadas escolas em vários locais, tanto em São Paulo como nas outras províncias, sustentadas em parte pelos pais dos alunos e por fundos da missão.

\section{Escolas democráticas e não-proselitistas}

De acordo com Ribeiro (1981), as escolas norteamericanas notabilizavam-se por enfatizar um ensino em que a tônica era a solidariedade e o individualismo ético, em que imperavam valores como honra, virtude, respeito mútuo, temperança e liberdade, derivados da religião e do acatamento de seus preceitos. Buscava-se motivar e incentivar os alunos a seguir um modelo de educação que propiciasse mudanças comportamentais e instituísse valores diferenciados na sociedade brasileira, que não aqueles calcados no modelo clerical católico.

Intelectuais formadores de opinião como Rui Barbosa, Rangel Pestana, Caetano de Campos, entre outros, viam com simpatia essa forma de os protestantes veicularem sua cultura e moldarem sua identidade, e não foram poucos os que consideravam o "modelo cultural" norte-americano algo a ser seguido e implantado no país, que procurava organizar um sistema de ensino que o equiparasse às grandes nações do mundo.

Com a criação e o funcionamento das escolas norte-americanas, a prática protestante começava a erigir novos valores sociais, como os pais investindo nas escolas, colaborando para pagar professores e ajudando os filhos sempre que possível, ao mesmo tempo em que se valorizava o trabalho das mulheres como educadoras de crianças e se implantava a co-educação dos sexos, princípios adotados no norte dos Estados Unidos desde 1850, aproximadamente. Nesse período, estudantes brasileiros iam à nação norteamericana completar sua formação, diferentemente dos tempos monárquicos, quando a referência era a Europa. No Brasil, os protestantes desejavam formar elites em suas escolas, que, convertidas ou não, abraçassem seu modelo cultural e ético voltado para valores como trabalho, moderação, religiosidade, respeito. Queriam formar seres humanos semelhantes àqueles de seu país, imbuídos de ideais democráticos e do desejo de servir à Deus e à pátria, e que fossem agentes de mudanças sociais. Na orientação pedagógica nas escolas evitavam o proselitismo, não exigiam conversão à sua fé, nem a observação de seus preceitos religiosos. Mas, nos relatórios enviados à junta, demonstravam inequivocamente que também queriam formar pastores para dar prosseguimento à sua missão e atrair os jovens para o protestantismo.

$\mathrm{Na}$ organização das escolas utilizavam os prin- 
cípios de classificar os alunos por seu índice de inteligência e aplicação, criticando a falta de homogeneidade das classes nas escolas brasileiras. Pregavam a liberdade e a democracia como valores essenciais na formação do cidadão. Os presbiterianos vindos do Norte opunham-se à escravidão e ao monarquismo que, segundo seus princípios, contaminavam a sociedade brasileira e inculcavam valores antidemocráticos, perniciosos a uma sociedade bem organizada. Nos cursos, instituíram o ensino graduado com classes de ler, escrever, dominar as quatro operações, as aulas de inglês, geografia, português, latim, francês, alemão, grego. Em continuidade aos anos iniciais básicos, abriram um curso acadêmico com matérias como matemática, línguas, história, geografia, filosofia, física, química, direito público. O ensino religioso veiculava valores morais e éticos, no qual se pregava o valor dos indivíduos por sua honradez, virtude e o respeito pelo Criador.

Em 1870, quando Mary Chamberlain organizou em São Paulo a classe para meninas protestantes, a grande procura fez com que o reverendo Chamberlain considerasse que o sistema escolar do Império era insuficiente, e que era preciso haver um lugar para ensinar a todos aqueles que eram perseguidos nas escolas públicas, fossem ou não protestantes. As mesmas reflexões fizeram Georg Nash Morton e Edward Lane, ministros presbiterianos que haviam chegado em 1868 com o objetivo de determinar qual o melhor lugar para sediar a missão no Brasil.

O reverendo Lane, de origem inglesa, era do Nashville Committee das Igrejas do Sul dos Estados Unidos, tendo estabelecido o centro de suas atividades missionárias na região de Campinas. Em 1870, Lane e Morton fundaram em Campinas a Igreja presbiteriana e a escola que funcionou por um ano. Em 1873, a escola organizou-se melhor e teve funcionamento contínuo; nela lecionou miss Nanie Henderson, e posteriormente veio ajudá-la miss Mary Videau, e também John W. Dabney, para lecionar no College. Estava iniciando-se o funcionamento do Colégio Internacional de Campinas, que em 1875 recebeu a visita do Imperador D. Pedro II.
Em outubro de 1871, Chamberlain organizou uma reunião em São Paulo com o objetivo de conseguir apoio para a fundação do College. Os missionários Morton e Lane também estiveram presentes, e em dezembro realizaram reunião similar para fundar o colégio de Campinas. Obtido o apoio da Board of Foreign Missions of the Presbyterian Church de Nova York, a escola deveria ministrar educação evangélica segundo os princípios da moral protestante; ficava excluída a propaganda religiosa, e a religião limitarse-ia às questões éticas e morais. Os filhos dos republicanos e abolicionistas seriam recebidos, assim como os filhos dos escravos. O sistema seria co-educativo; o ensino deveria ser pago para dar conta das despesas, pois a escola não teria fins lucrativos; haveria bolsas de estudos para os mais pobres e, se possível, elas seriam oferecidas àqueles que desejassem seguir a carreira missionária; doações poderiam ser aceitas e utilizadas para a melhoria do ensino, e a escola também alfabetizaria adultos. $\mathrm{Na}$ organização didática, a escola deveria introduzir o método intuitivo e a leitura silenciosa, diferentemente das escolas brasileiras que ainda seguiam o costume de leitura em voz alta e a decoração, conforme a tradição herdada dos jesuítas. $\mathrm{O}$ ensino deveria ser desenvolvido utilizando-se de manuais escolares próprios, de acordo com os padrões norte-americanos. O colégio deveria funcionar com uma Elementary School, um Secondary School, a Junior High School, a Senior High School além de organizar um Preparatory Course for College e uma Scientific School. Instituiuse a semana de cinco dias, excluindo-se as aulas aos sábados, e o ano letivo deveria ter 190 dias. O colégio adotaria o regime co-educativo, e a língua utilizada seria o português. Dar-se-ia ênfase ao treinamento manual, à ginástica e aos esportes em geral, e os turnos funcionariam em regime de internato.

De acordo com os princípios norte-americanos, considerava-se que, sendo a educação um direito do indivíduo, existia também a obrigação de garanti-la indistintamente a todos, independentemente da raça, da cor, do sexo ou da classe social. A propaganda religiosa seria excluída e a função do ensino religioso 
seria apenas debater valores éticos e morais, descartando-se o proselitismo. A abertura oficial deu-se em 1872, sendo nomeado como diretor o reverendo Chamberlain, e como vice-diretor o reverendo Robert Lenington. Posteriormente, criou-se a Training School, destinada a formar professores. Em 1877, inaugurou-se o Kindergarten, com método de ensino baseado em Froebel, que seria dirigido por uma professora vinda dos Estados Unidos, miss Phoebe Thomas.

Para Chamberlain, a formação de professores era uma tarefa urgente. Para o missionário, as escolas de nada valeriam sem mestres eficientes para garantir seu bom funcionamento e a aprendizagem dos alunos. A Training School, criada em 1875, destinava-se a preparar os futuros contingentes de professores que seriam os encarregados de ministrar ensino primário. O curso possuía o currículo organizado com disciplinas como: metodologia do ensino, pedagogia, higiene escolar, psicologia aplicada, matemática, português, geografia, história, música e educação física, com duração de três anos. A idéia da co-educação dos sexos no período pós-República começava a ter melhor aceitação no sistema público de ensino, inclusive nas escolas normais, o que significava um avanço em termos sociais, apesar de a existência de classes mistas não ser uma novidade no interior da província de São Paulo nas escolas de primeiras letras, derivadas de necessidades regionais.

No ano de 1886 a Training School foi transformada na Escola Normal do Mackenzie College. Veio dirigi-la miss Marcia Browne, missionária e professora norte-americana, considerada uma grande especialista no método intuitivo. Em 1896 foi inaugurada uma Escola de Engenharia no Mackenzie que seguiria os mesmos princípios de suas congêneres norteamericanas: laboratórios, trabalho de campo, professores em tempo integral, teoria e prática caminhando juntas. Horace Lane, ao assumir a direção do colégio, deu nova vitalidade à tão sonhada escola de Chamberlain. Posteriormente, Lane colaboraria com o governo de São Paulo como consultor educacional de Caetano de Campos e Cesário Mota, os organiza- dores do ensino público nesse estado. Horace Lane pode ser considerado um nome de destaque no ensino paulista, e ele próprio reconheceria o valor de duas professoras: miss Mary Dascomb e miss Ella Kuhl.

\section{A educação como missão: vestígios da presença feminina}

Mary Parker Dascomb, nascida em Providence, Rhode Island, em 1842, era filha de missionários e educadores. Havia vindo uma primeira vez ao Rio de Janeiro como preceptora dos filhos do cônsul norteamericano, tendo voltado dois anos e meio depois para os Estados Unidos. Em 1869 foi convidada por Simonton para integrar a equipe missionária. Alguns anos depois dirigia a mission school de Brotas, na província de São Paulo. Percorreu as várias vilas da província, como Botucatu e Rio Claro, indo depois viver no Paraná, onde, juntamente com Ella Kuhl, fundou a Escola Americana de Curitiba. Durante o período de 1886 a 1907 escreveu várias cartas a Horace Lane, relatando desde fatos corriqueiros até sua preocupação com o ensino protestante no Brasil, reafirmando sua fé e sua crença no valor da ação missionária educativa.

Ella Kuhl também nasceu em 1842, em Cooper Hill, pequena cidade em Nova Jersey, e formou-se professora pelo Women's College. Em 1865 foi nomeada professora de escola pública e veio para o Brasil trabalhar como missionária. Lecionou primeiramente em Rio Claro, e em 1877, com Mary Dascomb, foi para São Paulo, onde lecionou na Escola Americana. Durante certo tempo, ambas deram aulas em Botucatu. Em 1892 foram para Curitiba, onde se radicaram e fundaram a Escola Americana de Curitiba. As duas professoras permaneceram no Brasil até 1917, ano em que, com apenas um dia de diferença, viriam a morrer - Ella Kuhl nos Estados Unidos e Mary Dascomb em Curitiba (Goldman, 1961, p. 253).

O magistério exercido por mulheres, a co-educação dos sexos, a implantação de uma prática educativa inovadora e uma visão de mundo diferenciada ganharam a simpatia dos intelectuais reformadores, e 
as escolas protestantes, durante um determinado período, firmaram-se como centros de excelência irradiadores de modernas metodologias, passando a ser aceitos também pela classe média ascendente urbana e por uma pequena burguesia progressista. Ao findar o século XIX, a província de São Paulo contava com vários estabelecimentos de ensino denominados Escolas Americanas. Essas escolas passaram a fazer parte da oferta de ensino regular num sistema escolar que tentava firmar-se na educação paulista, e chegaram mesmo a destacar-se no cenário nacional, sendo reconhecidas pelas autoridades brasileiras, colaborando na construção da cultura, da nacionalidade e da identidade do país. Ao veicularem o trabalho feminino como forma de elevação moral e espiritual, de acordo com seus preceitos religiosos, e instituírem a coeducação para ambos os sexos, descortinaram uma nova perspectiva educacional, diferente da pregada pelos colégios católicos e até mesmo pelo ensino público, introduzindo premissas liberais vigentes nos Estados Unidos e que em São Paulo ainda eram vistas com certo receio pelos setores conservadores da sociedade civil e da Igreja católica.

Os protestantes, ao adotarem uma forma sacralizada de pensamento e comportamento, viam a educação como uma missão ordenada do alto, um atalho necessário para chegar à evangelização. Imbuídos de um ideal de renúncia e crença, podiam abandonar a terra natal e partir em missão no estrangeiro suportando os gentios, o clima, as doenças, a ausência da família e amigos. Definida pelos limites da instituição religiosa, a educação era a forma divina de servir, o que não retirava de sua prática a conotação política e ideológica de levar aos recantos mais longínquos a cultura e a ideologia que professavam, numa busca da hegemonia daquilo que consideravam o verdadeiro modo de ser e proceder. No missionarismo protestante talvez o mais forte elemento definidor da identidade fosse o inimigo comum: a Igreja católica. Havia, portanto, um confronto quanto aos conceitos de educação feminina entre católicos e protestantes, hipótese que pode ser adotada em futuros estudos da história da educação brasileira.
Durante os anos iniciais do século XIX, nos Estados Unidos, o ressurgimento do protestantismo evangélico deu novo ímpeto e urgência à convicção de que a nação requeria um novo tipo de mulheres educadas. A emergente república protestante estabeleceu novos conceitos de gênero e educação para responder à delicada questão da necessidade de educar as jovens que se preparavam para serem as futuras mães e educadoras dos filhos (Tyack \& Hansot, 1990). Se nos séculos anteriores a visão aristocrática e clerical retratava as mulheres como diversão ou um fardo a ser suportado, o protestantismo vai-lhes conferir um status especial de companheira do homem na criação das virtudes necessárias para erigir a América, a nova terra que vai servir de exemplo para o mundo civilizado. Nesse cenário, as mulheres, por sua posição moral privilegiada como principais detentoras dos valores cristãos, sua obrigação no lar, a sacralização da maternidade e seus deveres foram objeto de grande atenção na obra missionária. Mesmo assim, estavam longe de alcançar plenos direitos de cidadania, justamente por sua posição situar-se sempre um degrau abaixo dos homens na escala social, não podendo votar, freqüentar cursos superiores e assumir o controle da própria vida.

Em 1851, Edward Mansfield, político norte-americano, declarava que homens e mulheres possuíam os mesmos direitos sob o governo republicano - men and women are equal before the law of God -, expressando assim a idéia de que os direitos são alicerçados na natureza e na alma de todos os indivíduos, sendo, por sua vez, derivados dos ensinamentos bíblicos. Portanto, as diferenças políticas ou psíquicas eram irrelevantes ante o direito de uma educação plena para todos os cidadãos republicanos (Tyack \& Hansot, 1990, p. 31). Essa idéia iria conflitar com alguns pressupostos da época, segundo os quais, se as mulheres recebessem a mesma educação que os homens, tomariam caminhos desregrados e os papéis a serem desempenhados pelos sexos sofreriam inversões perigosas. Da mesma forma que os positivistas brasileiros, os norte-americanos defenderam a tese de que educar as mulheres era uma maneira de educar os 
homens, e a sociedade colocava as mães e as professoras sob suas bênçãos, incumbindo-as de preparar os futuros cidadãos da nação que se definia no cenário mundial.

Após a Guerra Civil Americana, a geração que a sucedeu conviveu com transformações na política e na economia, havendo empenho dos homens públicos na criação de um novo país, que deveria expandirse comercial e industrialmente, fortalecendo as raízes do capitalismo no Estado moderno. A imigração estrangeira, mais a grande mobilidade geográfica e a rápida urbanização, promoveriam uma progressiva desigualdade de riqueza e de renda, aprofundando o abismo entre as classes sociais. Os educadores discutiam esses problemas, debatendo como solucionar a pobreza dos imigrantes e as formas de assimilá-los à nova terra pela educação, que deveria ser igual para todos. Nesse discurso, embora se falasse em igualdade, havia diferenciações nas propostas educativas: se, para os homens, objetivava colocá-los em pé de igualdade social, para as mulheres a intenção era melhorar seu desempenho nos lares. Mesmo aqueles que advogavam a educação feminina não aceitavam seu trabalho ou sua área de atuação fora do lar ou da família, constituindo-se exceções as professoras e as missionárias, que também acumulavam o ofício de educadoras.

Desde os anos iniciais da sua República, no final do século XVIII, os norte-americanos debatiam vigorosamente sobre as características que deveria possuir a educação feminina, calcados no ideal de new nation, new woman pregado pelos republicanos. Os reformadores da educação passaram a contrapor-se à antiga idéia segundo a qual faltavam às mulheres capacidades intelectuais para a escolarização, e que mulheres educadas induziam ao estereótipo das velhas solteironas e afetadas. A nação precisava de um novo tipo de mulher e de mãe, educada não para exibicionismos nos salões, mas para criar cidadãos virtuosos e racionais. A mulher dos novos tempos não deveria mais se parecer com a matrona romana ou a coquete fútil, mas ser vista como a guardiã dos filhos e a companheira valiosa do homem. Essa mulher não se deveria inserir na vida pública nem se corromper na política já que dela não se esperava que administrasse a sociedade e fizesse as suas leis, e sim ser aquela que formaria caracteres e manteria a moral do lar cristão.

Mesmo assim, havia divergências e controvérsias sobre a educação feminina. Se, de um lado, os reformadores pregavam as virtudes das mulheres, e que essas seriam ampliadas pela educação, por outro lado, segmentos mais conservadores ridicularizavam seu aprendizado, considerando as mulheres educadas an amazon of intellect. Os debates foram ganhando força conforme a nação estendia seu poderio e estruturavase como sociedade eminentemente capitalista que lançava seus olhos para o mundo que se desenhava no final do século XIX, um mundo que deveria ser conquistado e convertido. Nesses debates, as opiniões sobre a correta educação das meninas eram publicadas em jornais, livros e revistas em que também se discutia sobre suas capacidades intelectuais. Nos púlpitos, ministros descreviam o ideal do caráter feminino plasmado pela educação; políticos demonstravam que a nova ordem republicana requeria uma forma diferente de educar as moças, e as ativistas feministas reivindicavam que, nos novos tempos republicanos de liberdade, as mulheres deveriam não só ter uma educação cuidadosa e igualitária, como poderiam atuar em todos os níveis da sociedade e exercer o direito legítimo de fazer parte do corpo social da nação que se edificava sobre uma perspectiva ideal de vida. Desse ponto de vista, a educação das filhas não deveria ser mais negligenciada que a dos filhos, e moças e rapazes deveriam receber igual educação.

Horace Mann, um dos mais conhecidos educadores norte-americanos do século XIX, considerava que cabia à mulher servir à nação fora da política. Porém, em virtude da sua dignidade intrínseca e sua importância como educadora, a ela deveria ser confiada a educação das crianças e dos jovens, na família e na escola. Para Mann, a chave da estabilidade política estava no lar, onde as mães poderiam criar indivíduos fortes e compenetrados dos direitos dos cidadãos. O destino feminino esculpia-se na certeza de o 
futuro da nação estar nas mãos das mulheres, como educadoras da infância. Para Mann, os conflitos políticos eram problemas de socialização entre os jovens: "The proper instruction of children was thus the political, religious, and domestic duty of the welleducated woman citizen, a way to fulfill her feminine destiny" (Mann apud Tyack \& Hansot, 1990, p. 35).

Na primeira metade do século XIX, nos Estados Unidos, os defensores da educação feminina eram ativistas do movimento religioso evangélico, cuja doutrina santificava e legitimava um papel mais ativo para as mulheres nas igrejas, na educação e na reforma social. Embora acreditassem que o destino da mulher era ser esposa e mãe acima de qualquer atividade, muitos reconheciam que uma educação efetiva permitiria que moças solteiras exercessem a honrada carreira de professora, naquilo que se denominou professionalizing motherhood, ou seja, a profissionalização da maternidade, assim entendida por atribuirse ao magistério feminino as mesmas qualificações sacralizadas da sublime missão maternal. Ao defender-se que na religiosidade e na moralidade as mulheres eram superiores aos homens, também se acreditava que o conhecimento era perigoso sem a religião, pois our reponsability is to God, and our highest interest is to please him.

$\mathrm{O}$ caráter protestante revelava-se nessas afirmativas, e as mulheres versadas na doutrina religiosa seriam as mais indicadas para ensinar na família e na escola. $\mathrm{O}$ trabalho educativo visto como ato missionário fez com que mulheres enfrentassem os perigos na fronteiras ainda selvagens de seu país e se aventurassem por terras estrangeiras perseguindo o ideal de, pela educação e religião, servir a Deus e à pátria, num senso de dever em que o desprendimento e a austeridade casavam perfeitamente com a proposta republicana de erigir uma grande nação que se destacaria entre as maiores do mundo. Para as mulheres, a educação também significava a possibilidade de escolher. O casamento não seria mais um dever e um destino inevitável, e o magistério seria a alternativa honrosa ao matrimônio. Mediando essas escolhas, uma idéia de liberdade, noção tão cara aos objetivos norte-americanos.
O magistério era a profissão ideal para as mulheres, adaptava-se perfeitamente bem à sua natureza, e educar era, acima de tudo, também uma causa. Além disso, era uma carreira compatível com o casamento. Poderia mesmo significar uma preparação para o matrimônio para as solteiras que freqüentassem os cursos de formação de professoras, pois estes não eram cursos para produzir celibatárias, muito pelo contrário, ajudariam a formar as futuras mães de família e a esposa ideal para ser a companheira do homem. No entanto, de um modo geral, a idéia de mulheres invadindo o espaço público, fosse no trabalho ou na política, trazia subjacente a certeza do perigo que isso representaria para si próprias e os riscos morais a que seriam submetidas, além da possibilidade de excitar os homens com sua presença, causando danos morais à sociedade, visão compatível com o puritanismo protestante e o conservadorismo católico, e que era veementemente contestada pelas militantes feministas dos anos iniciais do século XX. A máxima he for God only, she for God in him trazia a idéia da responsabilidade dos dois sexos na construção social, e nesta não estava prevista a concorrência entre os dois sexos, devendo a mulher ser mantida no lugar de sua competência, o lar, e ser treinada na obediência às leis, o mais salutar poder do mundo: "Training in obedience, in perception, in worships, in the consente of the mind to the reign of law, in the appreciation of differences in value, and in reverence and love these three fundamentals lie at the root of all progress, of all education" (Hazard, 1900, p. 30).

A crença na vida eterna explicita-se em um ponto de vista segundo o qual seria impossível dizer o que se deveria esperar em termos espirituais do homem ou da mulher, pois a alma tanto pode estar hospedada num corpo masculino como num corpo feminino. Quanto ao potencial cognitivo, uma mulher poderia, assim como qualquer homem, ser filósofa e outra detestar filosofia; ou uma possuir espírito e outra não possuir nenhuma habilidade espiritual. Esse modo de pensar apoiava-se epistemologicamente nas idéias de Platão, e defendia que os dons da natureza eram igualmente distribuídos entre homens 
e mulheres. Estas não eram apenas as belezas da vida, as mantenedoras do lar, as moralizadoras da sociedade, nem seus atributos intelectuais e físicos estariam somente voltados somente para o conservadorismo, a graça, a pureza e a reprodução. Portanto, sua educação não poderia estar voltada somente para esses atributos e sua ação não se circunscreveria somente à esfera do lar e ao desenvolvimento da função materna.

As principais revistas femininas publicadas nos Estados Unidos no período de 1830 a 1860 veiculavam histórias de amor, cartas, novos itens domésticos, poemas, e mesclavam esses assuntos intimistas com a educação e com a idealização da carreira de professora, além, obviamente, da missão sagrada da maternidade. Isso possibilitava a manutenção da situação social e familiar das mulheres e modelava a organização curricular das escolas femininas, não avançando efetivamente na meta de igualdade auspiciada pelas feministas. As publicações do período não comungavam efetivamente com o ideal de que o magistério de crianças deveria ser destinado exclusivamente às mulheres.

A destinação feminina acabava por colocar as mulheres numa esfera do mundo do trabalho que se inseria num plano secundário, dado que até 1830 os homens é que eram professores. Dentre os que procuravam pelo magistério estavam aqueles que não tinham obtido sucesso em outros campos, ou eram recémgraduados, ou estudantes de faculdades e academias que trabalhavam um ano ou dois nas salas de aula antes de procurar profissões mais lucrativas.

Com o aumento das escolas públicas nas décadas seguintes, e com a agricultura e a indústria solicitando o trabalho masculino, para suprir a necessidade de professores erigiu-se um imaginário que alocava às mulheres a missão de desempenhar a nobre tarefa de ensinar, bem de acordo com o que a sociedade delas esperava em termos de uma existência de renúncia, sacrifícios e desprendimento. Conseqüentemente, as normal schools, criadas para treinar professores, acabaram por associar-se intimamente às necessidades da educação feminina.
As professoras e os professores eram considerados os agentes de Deus para desempenhar uma grande tarefa; seu concurso era imprescindível para o avanço intelectual, social e moral do mundo, estando, antes dos ministros, no topo da escala de maior importância na sociedade. Para as mulheres, era a sacralidade vocacionada, o cumprimento dos desígnios de Deus, além de representar um ato de heroísmo e de patriotismo. Nas revistas do período, histórias eram publicadas nas quais a professora era a heroína que a tudo vencia em nome do amor à profissão; em outras, era a moça abandonada pelo noivo e que, por uma vida de paciência e resignação, triunfava graças ao seu amor pelos alunos. Paradoxalmente, alguns artigos se referiam à situação precária da educação no país, lamentando as deploráveis condições das escolas para a formação de professoras, a desqualificação destas e o parco conhecimento que possuíam, problemas que se refletiriam nos alunos pelo "bad English, bad habits, bad manners and too often bad morals", conforme publicado no Western Monthly Magazine and Literary Journal em abril de 1837 (Hazard, 1900, p. 96).

As décadas seguintes concretizaram os ideais educativos norte-americanos quanto à educação feminina. Quando os missionários protestantes se dirigiram ao Brasil na sua missão evangelizadora, trouxeram esposas e filhas que iriam desempenhar a tarefa de educar, juntamente com a pregação religiosa, enquanto eles se incumbiam dos atos públicos de fundar igrejas e escolas, construir edifícios e participar da vida política do país. As mulheres que acompanhavam os missionários foram para as salas de aula, organizaram e administraram os colégios e as escolas paroquiais, encarregando-se também das obras caritativas e de salvação, desempenhando o seu próprio destino manifesto de serem as responsáveis pela educação das futuras gerações e iluminar sua existência com os ditames da verdadeira fé. Nesse mister, que também era vocação e ofício divino, defenderam a co-educação, prática advinda da necessidade de não segregar alunos por conta do sexo e fornecer a meninos e meninas a mesma educação, na esteira de um 
ideal democrático de igualdade que se estava alicerçando em seu país de origem.

Os vestígios de sua passagem são tênues, assim como das demais mulheres educadoras que atuaram na educação brasileira. Seus nomes podem fornecer alguns sinais para estudos que privilegiem maiores aprofundamentos na história da educação. É um campo ainda a ser estudado, para que se possa fazer a história das mulheres alinhada com sua indiscutível presença na educação escolar. Talvez com isso possamos fazer uma história isenta de discriminação e revestida de alteridade.

\section{Referências bibliográficas}

BRAZIL-MISSION. USA, Washington D.C.: Rand Corporation, 1833-1911 (col. de microfilmes - rolls 34, 147, 148, 149).

CONFERÊNCIAS Populares da Freguesia da Glória no Rio de Janeiro, (1883). Atas e Pareceres do Congresso de Instrução do Rio de Janeiro. Rio de Janeiro: Tipografia Nacional, 1884.

GOLDMAN, Frank. Cartas de Mary P. Dascomb. São Paulo: Anais do Museu Paulista, 1961, tomo XV.

. Os pioneiros americanos no Brasil: educadores, sacerdotes, covos e reis. São Paulo: Pioneira, 1972.

HAZARD, Caroline. Some ideals in the education of women. New York: Thomas Y. Crowell and Co. Publishers, 1900.

MACKENZIE. 126 anos de história. São Paulo: Prêmio, 1997.

MENDONÇA, Antonio de G. O celeste porvir - a inserção do protestantismo no Brasil. São Paulo: Paulinas, 1984.

OLIVEIRA, Ana Maria C. de. O destino (não) manifesto: os imigrantes norte-americanos no Brasil. São Paulo: União Cultural Brasil-Estados Unidos, 1995.
RAMALHO, Jether P. Prática educativa e sociedade. Rio de Janeiro: Zahar, 1976.

RIBEIRO, Boanerges. Protestantismo e cultura brasileira: aspectos culturais da implantação do protestantismo no Brasil. São Paulo: Casa Editora Presbiteriana, 1981.

SIMONTON, Ashbel. Diário - 1852/1867. São Paulo: Casa Editora Presbiteriana, 1982.

TYACK, David; HANSOT, Elisabeth. Learning together: a history of coeducation in American schools. New York/London: Yale University Press, 1990.

WEBER, Max. A ética protestante e o espírito do capitalismo. São Paulo: Abril Cultural, 1981 (col. Os pensadores).

JANE SOARES DE ALMEIDA, livre-docente pela Universidade Estadual Paulista (UNESP), com pós-doutorado pela Harvard University e Universidade Autônoma de Barcelona, é docente do Programa de Pós-Graduação em Educação da Universidade Metodista de São Paulo (UMESP). Publicações mais importantes: Mulher e educação: a paixão pelo possível (São Paulo: Editora da UNESP, 1998); O legado educacional do século XIX (2. ed., Campinas: Autores Associados, 2006); O legado educacional do século XX no Brasil (2. ed., Campinas: Autores Associados, 2006); Ler as letras: por que educar meninas e mulheres? (Campinas: Autores Associados; São Bernardo do Campo, Editora Metodista, 2007). Pesquisa atual: "Meninas devem ler as letras? Educação feminina e co-educação dos sexos (São Paulo, 1931/1961)”, com bolsa de produtividade do Conselho Nacional de Desenvolvimento Científico e Tecnológico (CNPq). E-mail: jane.almeida@pesquisadorcnpq.br; janesoaresdealmeida@uol.com.br

Recebido em outubro de 2006 Aprovado em março de 2007 